\title{
PENGARUH DUKUNGAN KELUARGA TERHADAP PENINGKATAN ADAPTASI PASIEN SKIZOPHRENIA
}

\author{
${ }^{1}$ Vita Maryah Ardiyani, ${ }^{2}$ Kumboyono, ${ }^{3}$ Dian Susmarini \\ ${ }^{1}$ Program Studi Ilmu Keperawatan Fakultas Ilmu Kesehatan Universitas \\ Tribhuwana Tunggadewi Malang \\ ${ }^{2}$ Program Studi Ilmu Keperawatan Universitas Brawijaya Malang \\ ${ }^{3}$ Program Studi Ilmu Keperawatan Universitas Brawijaya Malang \\ e-mail:vitamaryah@gmail.com
}

\begin{abstract}
Adaptation is become accustomed to the need or new demand. It is an effort to seek reequilibrium into normal situation. Family support is such a help given from them in providing verbal or non verbal information, also behavior which gain emotional advantage. The aim of this research is to know the influence of family support with Skizophrenia's Patients Adaptation. I designed this research used analytical observational by cross sectional approach. There are 63 samples, they are patients of Skizophrenia which treated in Mental Hospital. Samples are taken by Simple random Sampling technique. Variables are measured through the level of family support and Skizophrenia's Patients Adaptation level. The measurement of family support used questionnaire, while measurement of adaptation by observation. The result of data analysis using test correlation of Rank Spearman are obtained correlation coefficient for about 0.427 probability (sign) for about (0.000) significant level is for about 95\% ( $a=$ 0.05). The value of correlation coefficient is bigger than table value. It showed that it was occurred significant relation between family supports of Skizophrenia's Patients and the increasing of Skizophrenia's Patients Adaptation. Good adaptation provides better patients' remission. I suggest to continue this research by observing regulator and cognate factor which influence adaptation, renovate instruments and methods of collecting data.
\end{abstract}

Keywords: Family Support, Adaptation, Skizophrenia

\begin{abstract}
ABSTRAK
Adaptasi adalah menyesuaikan diri dengan kebutuhan atau tuntutan baru yaitu usaha untuk mencari keseimbangan kembali kedalam keadaan normal. Sedangakan dukungan keluarga adalah bantuan yang diberikan oleh anggota keluarga yang dapat diandalakan yang berupa informasi verbal atau non verbal dan tingkah laku yang memberi keuntungan emosional. Penelitian ini bertujuan untuk mengetahui pengaruh dukungan keluarga dengan adaptasi pasien skizophrenia. Desain penelitian yang digunakan adalah obsevasional analitik dengan pendekatan cross sectional.Sampel sejumlah 63 pasien skizophrenia yang menjalani rawat inap di Rumah Sakit Jiwa, diambil melalui teknik Simple Random sampling. Varibel yang diukur meliputi tingkat dukungan keluarga dan tingkat adaptasi pasien skizophrenia. Pengukuran tingkat dukungan keluarga menggunakan kuesioner dan pengukuran tingkat adaptasi dilakukan dengan cara observasi langsung. Dari analisis data menggunakan uji korelasi Rank Spearman diperoleh koefisien korelasi sebesar 0.427 dengan probabilitas (sign) sebesar
\end{abstract}


(0.000) dan tingkat signifikasi 95\% $(\alpha=0.05)$. Nilai koefisien korelasi lebih besar dari nilai tabel. Hal ini menunjukkan terjadi hubungan yang signifikan antara dukungan keluarga pesien Skizophrenia dengan peningkatan adaptasi pasien Skizoprenia. Tingkat adaptasi yang baik dapat menunjang pancapaian remisi pasien yang lebih baik. Perlu diadakan penelitian lebih lanjut dengan meneliti faktor regulator dan kognator yang mempengaruhi adaptasi, memperbaiki instrument penelitian dan metode pengambilan data.

Kata kunci: Adaptasi, Dukungan Keluarga, Skizophrenia

\section{PENDAHULUAN}

Skizophrenia adalah salah satu gangguan jiwa yang sering terjadi dengan karakteristik gangguan integrasi otak yang mempengaruhi pikiran, perasaan dan afeksi (Rathus et al.,1991; Davison et al.,1994). Lebih lanjut Rathus menekankan pada tidak adanya kesesuaian antara pikiran dan kenyataan yang menimbulkan gangguan-gangguan kognitif, afektif, perilaku dan motivasi sehingga menyebabkan gangguan adaptasi pasien terhadap lingkungan. Skizofrenia seringkali menetap atau kronis, sering kambuh sehingga perlu terapi berjangka lama. Etiologi, patofisiologi dan perjalanan skizophrenia amat bervariasi sehingga mempersulit diagnosis dan penanganannya (Chandra,2004; Lestari, 2008).

Gangguan adaptasi pasien skizophrenia terhadap lingkungan merupakan hambatan dalam proses rehabilitasi pasien terutama bagi pasien-pasien yang ditempatkan di rumah sakit jiwa. Suatu terapi yang efektif ditandai dengan terbentuknya lingkungan terapeutik yang kohesif dan berkembangnya hubungan yang saling mendukung, sehingga dapat memberikan kesempatan perbaikan adaptasi terhadap disabilitas yang sebenarnya dapat menimbulkan gangguan emosi. Perilaku adaptif diharapkan dapat membantu pasien skizophrenia menjalani rehabilitasi di lingkungan RSJ sehingga dapat mencapai remisi yang lebih baik. Terapi skizophrenia yang berjangka lama juga memerlukan adaptasi pasien terhadap lingkungan, selain itu dukungan keluarga sebagai komponen yang terdekat dengan pasien sangat diperlukan.

Kecenderungan meningkatnya angka ganguan jiwa di kalangan masyarakat saat ini dan yang akan datang akan terus menjadi masalah sekaligus tantangan bagi tenaga kesehatan khususnya komunitas profesi keperawatan (Rasmun, 2001). Gambaran jumlah penderita di Rumah Sakit Jiwa (RSJ) Dr Soerojo Magelang, Jawa Tengah, jumlah pasien gangguan jiwa meningkat hingga 100\%. Jumlah pasien yang berobat pada 2005 sebanyak 330 orang per hari, tetapi pada tahun 
2008 mencapai 748 orang per hari sedangkan di RSJ dr Radjiman Wediodiningrat Lawang, Kabupaten Malang, Jawa Timur, terjadi peningkatan jumlah pasien gangguan jiwa sekitar 2\%-3\% selama tiga tahun terakhir. Saat ini sebanyak 650 pasien dirawat di sana, meningkat 20 orang dari tahun sebelumnya (Media Indonesia,2008). Sekitar 15\% penderita yang masuk rumah sakit jiwa merupakan pasien skizophrenia, Sebanyak 45\% populasi rumah sakit jiwa adalah pasien skizophrenia, dan sebagian besar pasien skizoprenia akan tinggal di rumah sakit untuk waktu yang lama (Ingram dkk, 1993).

Dukungan keluarga merupakan salah satu obat penyembuh yang sangat berarti bagi penderita Skizophrenia (Chandra, 2004; Parawita, 2006). Keluarga harus membantu menumbuhkan sikap mandiri dalam diri penderita. Mereka harus sabar menerima kenyataan, karena penyakit skizophrenia sulit disembuhkan.

Dukungan keluarga berperan penting pada fase residual skizoprenia dimana gejala gejala-gejala positif / psikotiknya sudah berkurang (Rasmun, 2004). Mengurung, mengucilkan atau menyingkirkan orang dengan skizofrenia hanya akan memperburuk kondisi mereka. Pasien skizophrenia perlu mengkonsumsi obat dalam jangka panjang. Keteraturan minum obat sangat penting untuk mengendalikan gejala dan mencegah kekambuhan.

Berdasarkan hal-hal tersebut maka dukungan keluarga dan masyarakat terhadap pasien-pasien skizofrenia menjadi hal yang sangat penting dalam proses penyembuhan selain obat-obatan dan terapi psikologi yang diberikan oleh tenaga kesehatan.

\section{METODE PENELITIAN}

Rancangan penelitian yang digunakan adalah observational analitik dengan pendekatan cross-sectional. Rancangan ini ditujukan untuk mengetahui ada atau tidaknya pengaruh dukungan keluarga dengan peningkatan adaptasi pasien Skizophrenia di lingkungan RSJ " $\mathrm{X}$ ". Populasi target penelitian adalah seluruh pasien Skizophrenia yang menjalani rawat inap di RSJ "X". Sampel dalam penelitian ini adalah pasien skizophrenia yang menjalani rawat inap dan mendapat kunjungan dari keluarga. Jumlah penderita pasien gangguan jiwa pada tahun 2008 yang dirawat di RSJ " $\mathrm{X}$ " berjumlah 509 orang. Penderita skizophrenia diperkirakan $15 \%$ dari penderita yang masuk ke RSJ. Dengan 
teknik simple random samping diperoleh sample sebanyak 63 orang. Jumlah sample dihitung dengan kriteria jumlah populasi kurang 1000 dengan menggunakan taraf signifikasi $(\mathrm{d}=0,05)$.

Metode pengumpulan data dalam penelitian ini menggunakan kuesioner dan observasi langsung. Peneliti datang ke rumah sakit jiwa tempat pasien skizophrenia dirawat inap dan mendapat kunjungan keluarga. Peneliti membagikan kuesioner dukungan keluarga untuk diisi oleh keluarga pasien kemudian peneliti bersama perawat melakukan observasi terhadap pasien untuk mengetahui adaptasi pasien di lingkunga rumah sakit jiwa. Kuesioner yang telah diisi dikumpulkan pada peneliti, untuk selajutnya dilakukan pengolahan dan analisis data.

\section{HASIL}

Berdasar Diagram 1 diketahui bahwa sebagian besar responden berada dalam rentang usia antara 20-30.

Berdasarkan Diagram 2 diketahui bahwa sebanyak 56\% responden berjenis kelamin perempuan.
Diagram 3 menunjukkan bahwa sebanyak $89 \%$ responden mengalami skizophrenia hebefren.

Diagram 1. Karakteristik Berdasarkan Usia Responden di Rumah Sakit Jiwa "X"

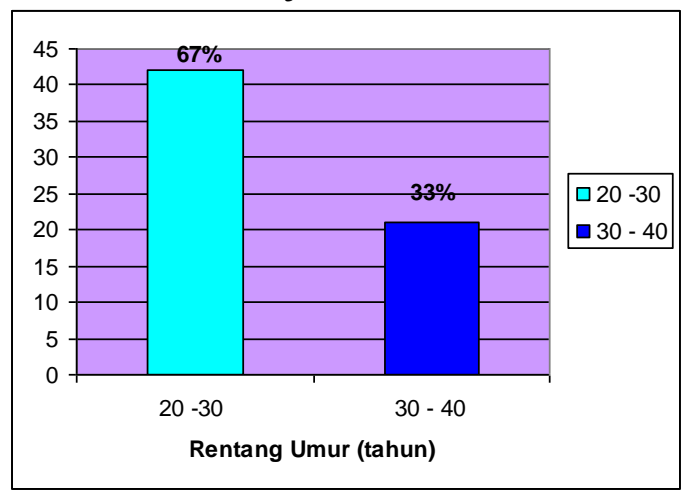

Diagram 2. Karakteristik Berdasarkan Jenis Kelamin Responden di Rumah Sakit Jiwa "X"

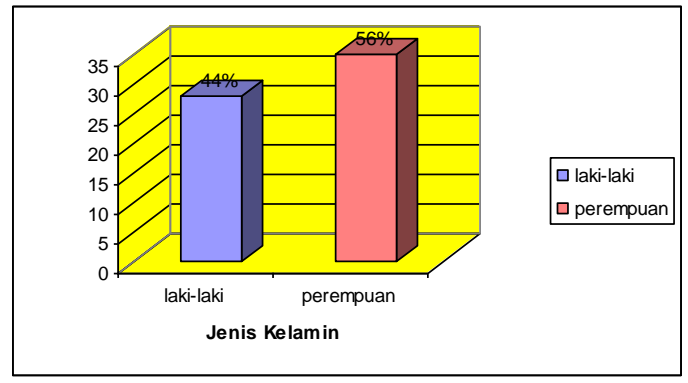

Diagram 3. Karakteristik Responden Berdasarkan Jenis Skizophrenia di Rumah Sakit Jiwa "X"

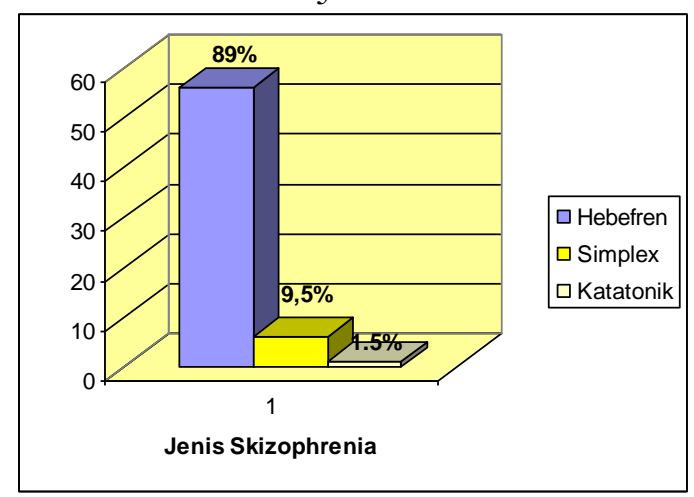


Karakteristik responden berdasarkan status pengunjung pasien didapatkan sebanyak $53,84 \%$ pengunjung adalah keluarga inti dari pasien, sedangkan sebanyak 10,16\% pengunjung bukan keluarga inti pasien.

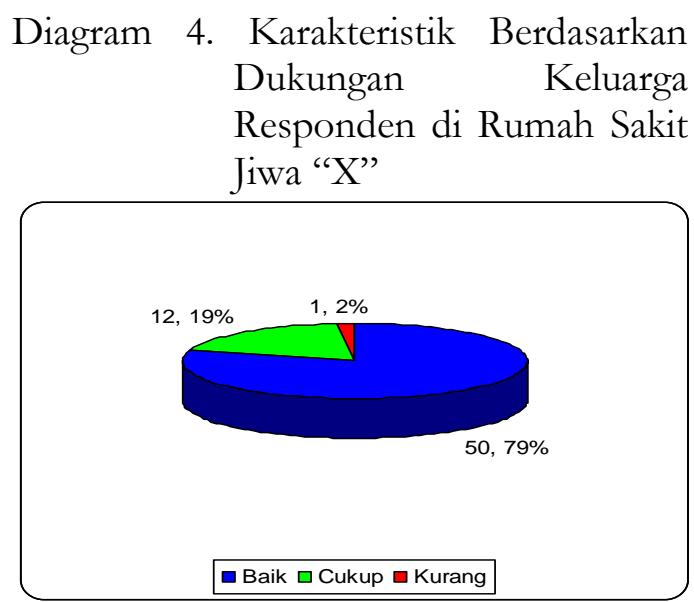

Berdasarkan Diagram 4 diketahui sebanyak $\quad 50,79 \% \quad$ responden mendapatkan dukungan keluarga dengan kategori baik.

Diagram 5. Karakteristik Berdasarkan Tingkat Adaptasi Responden di Rumah Sakit Jiwa "X"

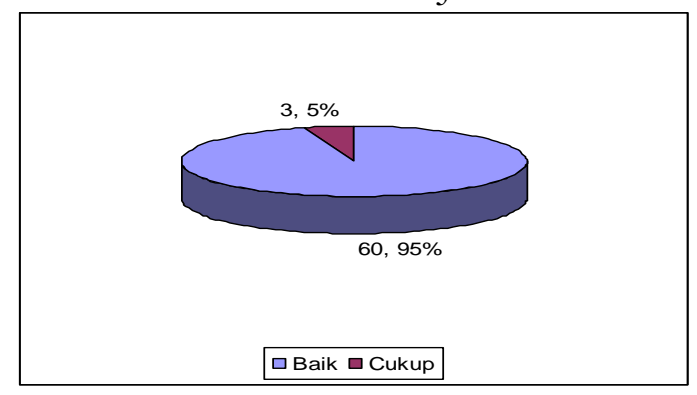

Berdasarkan Diagram 5 diketahui bahwa sebanyak $60,95 \%$ responden mempunyai tingkat adaptasi yang baik.
Selanjutnya untuk membuktikan pengaruh dukungan keluarga terhadap peningkatan adaptasi pasien dilakukan uji korelasi Spearman rank didapatkan hasil nilai koefisien korelasi sebesar 0.427 dengan probabilitas (sign) sebesar 0.000. Nilai ini lebih besar dari $\mathrm{r}$ tabel (0.427> 0.244) dan nilai probabilitas lebih kecil dari $0.05(0.000<0.05)$. Hal ini menunjukkan bahwa terdapat hubungan yang signifikan antara dukungan keluarga pasien skizophrenia dengan peningkatan adaptasi pasien pasien skizophrenia . Hubungan antar variabel bermakna positif, yang artinya jika dukungan keluarga pasien skizophrenia mengalami peningkatan, akan terjadi kecenderungan peningkatan adaptasi pasien skizophrenia.

\section{PEMBAHASAN}

\section{Dukungan Keluarga pada Pasien Skizophrenia}

Dukungan keluarga adalah bantuan yang diberikan oleh anggota keluarga yang dapat diandalkan yang berupa informasi verbal atau nonverbal dan tingkah laku yang memberi keuntungan emosional. Dukungan keluarga merupakan salah satu penyembuh yang sangat berarti bagi penderita Skizophrenia (Chandra, 2004; Parawita, 2006). Dukungan keluarga dapat berupa dukungan instrumental, dukungan emosional, dukungan 
penghargaan dan dukungan informatif (House dan Smett, 1994).

Hasil Penelitian menunjukkan bahwa sebagian besar responden yaitu $79 \%$ mendapatkan dukungan keluarga yang baik. Tingkat dukungan keluarga baik menunjukkan dukungan keluarga diberikan secara menyeluruh yaitu berupa dukungan instrumental, emosional, penghargaan dan informatif. Sebesar 19\% responden mendapatkan dukungan keluarga cukup. Pada tingkat dukungan keluarga cukup dapat dilihat kurangnya dukungan informatif dan penghargaan pada pasien skizophrenia. Kebanyakan pasien dengan tingkat dukungan keluarga cukup hanya mendapat dukungan instrumental dan emosional. Hanya 2\% pasien yang mendapatkan tingkat dukungan kurang. Pada tingkat dukungan keluarga kurang berarti penderita kurang mendapat 4 komponen dukungan keluarga tersebut diatas.

Sebagian besar dukungan keluarga didapatkan dari keluarga inti. keluarga inti adalah orang-orang terdekat pasien yaitu ayah, ibu, suami atau istri dan saudara kandung. Dukungan keluarga terutama dari keluarga inti sangat berperan bagi kondisi psikologis seseorang. Keluarga inti sebagai orang terdekat merupakan suatu sistem yang berinteraksi, saling ketergantungan dan saling menentukan satu sama lain (Rasmun, 2001).

Sebagian besar pasien skizophrenia yaitu $67 \%$ berada dalam rentang usia dewasa awal. Tugas perkembangan dewasa awal antara lain adalah fisiologis, kognitif, dan psikososial yang berupa tanggung jawab terhadap karir, pernikahan dan membuat atau membentuk tipe keluarga (Potter \& Perry, 2001). Sesuai dengan tugas perkembangan usia dewasa awal bahwa pasien skizophrenia membutuhkan dukungan keluarga untuk memenuhi tugas perkembangan terutama terhadap disabilitas yang dapat menimbulkan gangguan emosi.

Dukungan keluarga yang diberikan secara nyata dalam bentuk bantuan fisik, dukungan moral, mendengarkan masalah, bersikap empati, memberikan ketenangan dan kasih sayang serta memberikan bantuan dalam pemecahan masalah merupakan peran keluarga secara terapuetik (Friedman, 1998). Peran keluarga secara terapuetik berperan penting dalam individu yang mengalami masalah kesehatan terutama masalah kesehatan jiwa untuk mencapai mekanisme koping yang konstruktif terutama untuk mencapai tujuan terapeutik dan perilaku adaptif. 


\section{Adaptasi Pasien Skizophrenia Dilingkungan RSJ}

Adaptasi adalah mengaktifkan fungsifungsi kognator untuk penyesuaian atas masalah yang dihadapi. Pada penderita skizophrenia terdapat beberapa gangguan antara lain gangguan kognitif, afeksi, perilaku dan motivasi (Rathus et al, 1991). Gangguan-gangguan tersebut menyebabkan gangguan terhadap proses adaptasi. Perilaku adaptif dari pasien skizophrenia berupa kemampuan daya penyesuaian diri tehadap lingkungan yang ditunjukkan dengan bicara dengan orang lain (komunikasi), mampu menyelesaikan masalah, teknik relaksasi,dan aktifitas konsruktif (Rasmun, 2001).

Dalam penelitian menunjukkan bahwa sebagian besar responden, yaitu 95\% menujukkan tingkat adaptasi yang baik. Sebesar 5\% pasien skizophrenia menunjukkan tingkat adaptasi cukup. Pada pasien dengan tingkat adaptasi cukup sebagian besar pasien mengalami kendala dalam komunikasi dan pemenuhan ADL (Activity Daily Life). Tidak didapatkan pasien dengan tingkat adaptasi kurang dikarenakan penelitian dilakukan pada pasien skizophrenia pada fase residual dimana gejala-gejala psikotiknya sudah berkurang sehingga memulai berproses untuk beradaptasi dengan lingkungan. Adaptasi yang baik ditujukan untuk pembentukan koping yang konstruktif. Hasil Akhir dari upaya koping adalah suatu kondisi adaptasi yaitu perilaku baru dari hasil modifikasi selama proses adaptasi (Rasmun, 2004).

Sebanyak $67 \%$ pada penderita pria dan $33 \%$ penderita perempuan mempunyai tingkat adaptasi yang cukup. Perbedaan tingkat adaptasi pada laki-laki dan perempuan dipengaruhi berbagai faktor antara lain perbedaan peran laki-laki dan perempuan. Peran laki-laki antara lain yaitu mengontrol, independent, asertif, kompetitif, agretif dan manipulatif. Sedangkan peran perempuan adalah kebanyakan pasif, tergantung, tidak agresif dan hangat (Dusek, 1996). Karena peran tersebut laki-laki berpeluang lebih lama dalam beradaptasi. Pada pasien dengan tingkat adaptasi cukup terjadi pada pasien skizoprenia katatonik dan simplex. Hal ini sesuai dengan teori bahwa pada penderita skizophrenia katatonik tampak gejala aktivitas jauh berkurang, individu diam, tidak mau berkomunkasi dan sikap badan tegang dan biasanya dipertahankan untuk waktu yang lama. Sedangkan pada penderita skizophrenia simpleks tampak gejala penderita biasanya berkeinginan untuk berbaring, malas-malasan, jorok, tidur- 
tiduran, jarang mandi, motorik lamban, dan jarang berbicara (Coleman, 1976; Kartono, 1989).

Dalam penelitian ini pasien skizophrenia yang menjalani rawat inap dan berada dalam fase residual sebagai individu yang memulai proses adaptasi terhadap lingkungan baru di Rumah Sakit Jiwa. Dalam lingkungan baru ini pasien skizophrenia dihadapkan dalam berbagai situasi dan rutinitas sehari-hari maupun rutinitas terapuetik yang baru sehingga membutuhkan proses penyesuaian terhadap situasi dan rutinitas baru tersebut. Dengan adanya penyesuaian terhadap situasi dan rutinitas baru tersebut ditujukan untuk pencapaian tujuan terapeutik.

\section{Pengaruh antara Dukungan Keluarga dengan Peningkatan Adaptasi Pasien Skizophrenia}

Dari hasil analisis penelitian dengan bantuan Software SPSS15.0 For Windows. Diperoleh Nilai koefisien korelasi sebesar 0.427 dengan probabilitas (sign) sebesar 0.000. nilai ini lebih besar dari $\mathrm{r}$ tabel $(0.427>0.244)$ dan nilai probabilitas lebih kecil dari $0.05(0.000<0.05)$. Hal ini menunjukkan bahwa terjadi hubungan yang signifikan antara dukungan keluarga pasien skizophrenia dengan peningkatan adaptasi pasien pasien skizophrenia dan hubungan antara keduanya positif. Artinya jika dukungan keluarga pasien skizophrenia mengalami peningkatan, maka akan terjadi kecenderungan peningkatan adaptasi pasien skizophrenian dan demikian pula sebaliknya. Hasil ini memperlihatkan bahwa variabel dukungan keluarga pasien skizophrenia berhubungan secara signifikan dengan adaptasi pasien pasien skizophrenia pada level $5 \%$.

Hal tersebut sesuai dengan hipotesa penelitian bahwa dukungan keluarga mempengaruhi peningkatan adaptasi pasien skizophrenia di Lingkungan RSJ. Dukungan keluarga berpengaruh pada proses penyembuhan penderita skizophrenia. Dukungan keluarga sebagai keberadaan, kesediaan, kepedulian dari orang-orang yang dapat diandalakan (Sarason, 1983) berpengaruh pada adaptasi pasien Skizophrenia. Koping pada tingkat keluarga berupa dukungan keluarga dapat membatu proses adaptasi pasien skizophrenia terhadap lingkungan yang ditujukan sebagai sarana mencapai tujuan terapeutik.

Adapasi pasien skizophrenia sebagian besar menunjukkan tingkat adaptasi baik. Dimana pasien berada pada fase 
residual/maintenance, keadaan pasien sudah tenang dan mulai beradaptasi dengan lingkungan. Selain dipengaruhi oleh dukungan keluarga adaptasi juga dipengaruhi sistem regulator manusia yang menangani terhadap adanya rangsangan dari luar yaitu melalui sistem saraf dan hormonal dan sistem kognator yang menangani stimulus dengan melalui proses informasi, belajar dan mengambil keputusan (Rasmun, 2004).

\section{KESIMPULAN}

Dari penelitian tentang pengaruh dukungan keluarga terhadap peningkatan adaptasi pasien Skizophrenia dilingkungan RSJ, dapat disimpulkan bahwa :

1. Sebagian besar pasien skizophrenia mempunyai dukungan keluarga yang baik sebesar $79 \%$.

2. Sebagian besar pasien skizophrenia mempunyai tingkat adaptasi yang baik, yakni 95\%.

3. Dukungan keluarga memiliki pengaruh terhadap peningkatan adaptasi pasien Skizophrenia dilingkungan RSJ. Berdasrkan hasil analisis korelasi rank Spearman. Didapatkan hasil koefisien korelasi sebesar 0.427. nilai lebih besar dari $r$ table. Dukungan keluarga pasien Skizophrenia mengalami peningkatan, akan terjadi kecenderungan peningkatan adaptasi pasien Skizophrenia.

\section{REFERENSI}

Chandra, L.S. (2004). Schizophrenia Anonymous, A Better Future. www.jiwasehat.com. Diakses tanggal: 28 April 2008.

Coleman, J.C. (1976). Abnormal Psychology and Modern Life, 5 th edition.

Davison, G.C., Neale, J.M. (1994). Abnormal Psychology. New York, John Wiley \& SonInc.

Dusek, Jerome B. (1996). Adolencent Development and Behavior. Prentice Hall: New Jersey

Fakultas Psikologi, Universitas Padjadjaran. (1992). Psikoterapi, Penggunaan Psikoterapi Pada KasusKasus Klinis. Bandung

Friedman, Marry M. (1998). Keperawatan Teori dan Praktek. Jakarta: EGC.

House, Smett. (1994). Psikologi Kesehatan. Jakarta: EGC.

Ingram et al. (1993). Catatan Kuliah Psikologi. Jakarta: EGC.

Media Indonesia. (2008). Jumlah Pasien Gangguan Di Indonesia Meningkat. http://mediaindonesia.com/inde x.php?ar id=MjUyMDU=.

Diakses : tanggal 1 September 2008. 
Jurnal Care Vol .5, No2,Tahun 2017

Potter \& Perry. (2001). Fundamental

Nursing edisi 4. EGC: Jakarta

Rasmun. (2001). Keperawatan Kesehatan

Mental Psikiatri Terintegrasi Dengan

Keluarga. Jakarta : Fajar

Intrpratama.

Rasmun. (2004). Stres, Koping dan Adaptasi.

Jakarta :Sagung Seto

Rathus, S.A., Nevid, J.J. (1991). Abnormal

Psychology. New Jersey, Prentice

Hall, Englewood Cliffs. 